\title{
Results of Black Sea algal viruses monitoring
}

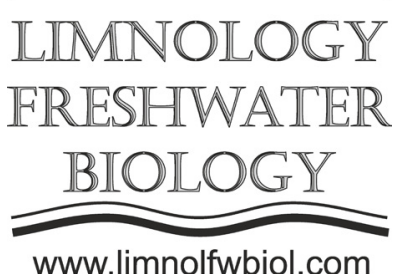

\author{
Stepanova O.A. \\ Institute of Natural and Technical Systems, Lenin St., 28, Sevastopol, Russia
}

\begin{abstract}
Search, isolation, study and monitoring of Black Sea algal viruses, new to science or new for the Black Sea ecosystem, has been carried out at the Sevastopol Institutes of for over 18 years. During this time more than 300 strains of algal viruses were isolated to seven species of microalgae and to one species of cyanobacteria from more than one thousand different samples (sea water, bottom sediments, mussels and fish). The purpose of the work is to summarize and analyze the results of long-term monitoring of the Black Sea viruses of microalgae (the stable Tetraselmis viridis and the demanding for environmental conditions Phaeodactylum tricornutum), that are two bioindicators of the environmental situation, from water samples of three Sevastopol bays, that differ in ecological status. The obtained data served as the basis for the assumption of relatively good ecological status in the studied water areas of Sevastopol bays in 2007-2008 and 2017-2020, and in 2002-2003, 2006 and 2015 about bad environmental (ecological) status. An analysis of the results indicates that studied two bays staying in relatively well ecologically status are characterized by isolation of the maximum number of viral strains of two bioindicatoral microalgae with a numerical predominance of viral strains of the $P$. tricornutum (environmentally demanding microalgae), in comparison with the same indices in a closed bay with bad ecologically status and staying in anthropogenic load. A shift of two months in the spring seasonality (in January - February) of algal viruses in 2019-2020 was noted.
\end{abstract}

Keywords: Algal viruses, bioindicators, microalgae Tetraselmis viridis and Phaeodactylum tricornutum, good (well) or bad ecological status of Sevastopol bays, Black Sea

\section{Introduction}

Monitoring of new for the science or for the Black Sea ecosystem algal viruses, primarily algal viruses of two bioindicators - microalgae Tetraselmis viridis and Phaeodactylum tricornutum - in the bays of Sevastopol and Crimea has been carried out for 18 years (since May 2002). Until 2014, work was carried out at the Institute of Biology of the Southern Seas (IBSS), and from 2015 research was continued at the Institute of Natural and Technical Systems of Sevastopol. Over the period from 2002 to the present, more than 300 strains of marine algal viruses were isolated from different samples (more than one thousand) - sea water, bottom sediments, mussels and fish. Among them were isolated new for the science algal viruses Tetraselmis viridis (TvV), Dunaliella viridis, Phaeodactylum tricornutum (PtV), Prorocentrum pusilla, Isochrysis galbana, Tisochrysis lutea. Also were isolated new viral strains for the Black Sea ecosystem - the viruses of microalgae Emiliania huxleyi and cyanophages to the cyanobacterium Synechococcus.

The purpose of the study is to analyze, generalize and evaluate the results of long-term monitoring of viruses of two microalgae $T$. viridis and $P$. tricornutum, which are bioindicators of the ecological situation, in three bays of Sevastopol, which are differ by ecological status. During the study, the following tasks were solved:

- analysis of the isolation frequency of algal viruses of $T$. viridis and $P$. tricornutum, as bioindicators of the ecological status, from three bays of Sevastopol for the period since 2002 with the identification of seasonality and annual features of their distribution, which would provide a basis for establishing the ecological status (good or bad status) in the studied waters at a certain time stage (year);

- comparative assessment of the isolation of algal viruses of $T$. viridis and $P$. tricornutum, indicative of the ecological status, from each of the three studied bays of Sevastopol for the period from 2015 to 2020 with the identification of the characteristic features of the distribution of algal viruses for bays with different ecological status.

\section{Materials and methods}

Search and isolation of algal viruses from seawater samples taken in three bays of Sevastopol, differing 
in environmental well-being (bays in comparatively good ecological status - open (K) and closed (M), and closed bay (A) with bad ecological status, staying under anthropogenic load) were performed using author patented methods (Stepanova, 2004; 2012). Liquid microalgae cultures were obtained from the department of IBSS. The isolation frequency of algal viruses was determined as the percentage of their isolation relative to the number of samples studied per year. The number of viral isolations corresponds to the number of strains of isolated viruses for a certain time.

\section{Results and discussion}

An analysis of the isolation frequency of viruses of $T$. viridis and $P$. tricornutum, microalgae indicative of the ecological well-being, from three bays of Sevastopol over an 18-year period indicates that the isolation frequency of virus of microalgae $T$. viridis, that is stable to environmental factors, was observed in the range of 54-44\% (2002 -2003, 2006 and 2015) to 3-0\% (20072009). For virus of $P$. tricornutum algae, demanding on environmental conditions, the isolation frequency ranged from $89-41 \%(2008,2017-2020)$ to $0 \%$ (2015). Moreover, a difference in the isolation frequency of $30 \%$ and higher between $\mathrm{TvV}$ and $\mathrm{PtV}$ was observed in 2002-2003 (31\%), 2006 (33\%) and in 2015 (52\%). Conversely, between $\mathrm{PtV}$ and $\mathrm{TvV}$, a difference in isolation frequency of $30 \%$ and higher was observed in 2008 (42\%), 2017 (30\%), 2018 (33\%) and 2020 (59\%). Seasonal peaks of isolation algal viruses were mainly observed in March - April and September - October, which corresponds to the seasonal peaks of their hosts in the Black Sea. In 2019 and especially in 2020 it was observed a shift in the spring seasonality of isolation of algal viruses by 2 months (in January - February), which may be due to abnormally warm winters in these years.

A comparative assessment of the number of viral isolation of viruses of $T$. viridis and $P$. tricornutum for the period from 2015 to 2020 from each of the three studied bays of Sevastopol revealed, that out of 71 strains $(100 \%)$, the maximum number was isolated from bays with the relatively good ecological status: 30 (42\%) from open bay $\mathrm{K}$ and 27 (38\%) from closed bay $\mathrm{M}$. The minimum number of virus strains - 14 (20\%) was isolated from a closed, environmentally bad bay A. Of 39 strains of algal virus of microalga $P$. tricornutum, which is environmentally demanding, 14 (36\%) and 18 $(46 \%)$ were isolated from water samples of relatively environmentally good bays ( $\mathrm{K}$ and $\mathrm{M}$ ), and only 7 (18\%) from the bay (A) with bad ecological status.

\section{Conclusions}

Based on an analysis of the monitoring results of the Black Sea algal viruses of two micro-algae, bioindicating environmental conditions, from the three ecologically different bays of Sevastopol, the following was established:

- Relatively ecological good situation in the studied water areas in 2007-2008 and 20172020 (maximum isolation frequency $\mathrm{PtV}$, and / or minimum isolation frequency $\mathrm{TvV}$, and / or maximum difference in isolation frequency between $\mathrm{PtV}$ and $\mathrm{TvV}$ );

- Bad ecological situation in the studied water areas in 2002-2003, 2006 and in 2015 (maximum isolation frequency $\mathrm{TvV}$, and /or minimum PtV, and /or maximum difference in isolation frequency between TvV and PtV);

- For the studied ecologically good bays, the maximum number of viral isolates (TvV and PtV) with a numerical predominance of viral strains of the algae $P$. tricornutum, which is environmentally demanding, is characteristic.

\section{Acknowledgements}

The work was performed as part of the state assignment on the state budget topic of Institute of Natural and Technical Systems № 0012-2020-0003.

\section{References}

Stepanova O.A. 2004. Patent of Ukraine for invention № 2003065499, Bull., № 4, 2004 (2003).

Stepanova O.A. 2012. Patent of Ukraine № 201003881 Bull., № 2, 2012 (2010). 